\title{
SYNTHESIS OF 1,3,8,8a-TETRAHYDRO-3,8-EPOXYAZIRINO[1,2- b]ISOQUINOLINES AND THEIR REACTIONS WITH OXYGEN NUCLEOPHILES
}

\author{
M. José Alves, * Nuno G. Azoia and A. Gil Fortes \\ Chemistry Department, Universty of Minho, Campus de Gualtar 4700-320 Braga \\ E-mail:mja@quimica.uminho.pt
}

\begin{abstract}
We have extended an earlier study of cycloadditions of $2 \mathrm{H}$-azirines to isobenzofurans. The endo and exo products were obtained and were reacted with oxygen nucleophiles. Tetrahydroquinolines or benzofuranols were obtained, usually in excellent yields. Cycloaddition of the less electrophilic azirine (14) was performed at room temperature in the presence of $\mathrm{ZnCl}_{2}$. The cycloadduct was hydrolysed in the reaction conditions, but dehydration to give back the original cycloadduct was obtained in the presence of $4 \AA$ molecular sieves. The structure assigned in the literature to the product of hydrolysis of the cycloadduct $\mathbf{1 0}$ was rectified.
\end{abstract}

\section{INTRODUCTION}

We studied earlier the reaction of alkyl $2 \mathrm{H}$-azirine-3-carboxylates with furan and furan derivatives. ${ }^{1}$ Methyl (2,6-dichlorophenyl)-2H-azirine-3-carboxylate reacts with furan forming the exo cycloadduct (1) quantitatively and so does the benzyl $2 \mathrm{H}$-azirine-3-carboxylate giving the cycloadduct (3). Hydrolysis product obtained from 1 gives a single adduct $\mathbf{2}$ (scheme 1). In contrast, a much more complex reactivity is shown in hydrolysis of adduct 3, giving four products: the cis (4) and trans (5) 1,3-dihydrofurans and cis (6) and trans (7) azabicycloheptenediols (scheme 2). ${ }^{1}$ Hassner and Anderson ${ }^{2}$ reported that several adducts could be obtained with total stereo-control from cycloadducts of 1,3-diphenylisobenzofuran with alkyl and aryl $2 \mathrm{H}$-azirines depending on the hydrolysis conditions. Scheme 3 shows conditions for exclusive formation of the cis (8) or trans (9) tetrahydroisoquinolines, according to the authors. As either the oxygen bridge or the $\mathrm{C}-\mathrm{N}$ bond are prone to break in these reactions we decided to take a further look at the reactivity of cycloadducts of $2 \mathrm{H}$-azirines with 1,3-diphenylisobenzofuran and isobenzofuran. To broaden the interest of such reactions we tried a less reactive $2 H$-azirine, the ethyl $2 H$-azirine- 2 
carboxylate. This would open up the possibility of forming chirally enriched products after reacting known chiral alkyl $2 \mathrm{H}$-azirine-2-carboxylates ${ }^{3}$ and $2 \mathrm{H}$-azirine-2-phosphonates ${ }^{4}$ with isobenzofurans. The hydrolysis and methanolysis products obtained were new tetrahydroisoquinolines fused to an aziridine ring formed with total stereo-control or 1,3-dihydroisobenzofurans attached to aziridine that either formed a 1:1 mixture of cis and trans isomers or a single product. The methanolysis product of the cycloadduct $\mathbf{1 0}$ was proved to be the furanol 27, rather than the tetrahydroquinoline $\mathbf{2 8}$, proposed before. ${ }^{2}$

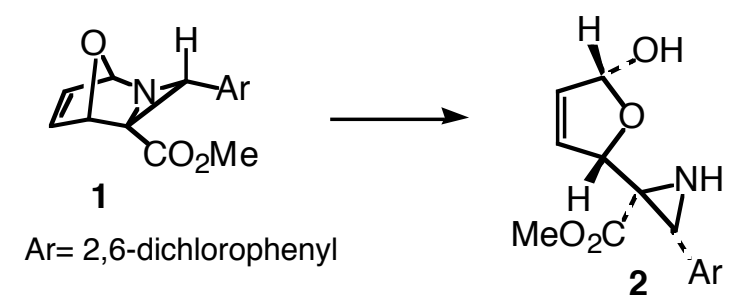

Scheme 1. Hydrolysis of adduct 1

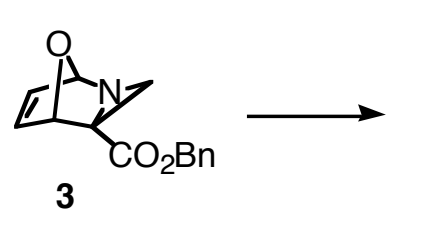

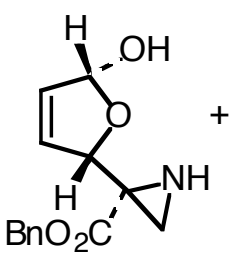

4<smiles>O=C(Br)C1(C2(CO)CN2)C=CC(O)C1</smiles>

5<smiles>CC1(C(=O)O)CN2C(O)C=CC(O)C21</smiles>

6<smiles>O=C(Oc1ccccc1)C12CN1C(O)C=CC2O</smiles>

7

Scheme 2. Hydrolysis of adduct 3<smiles>CC(C)(C)C1[C@](O)(c2ccccc2)c2ccccc2[C@]1(O)c1ccccc1</smiles>

8

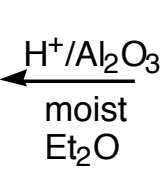

$\mathrm{Et}_{2} \mathrm{O}$

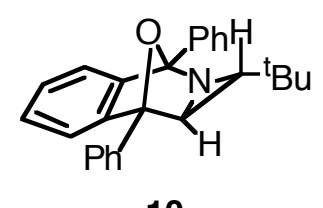

10

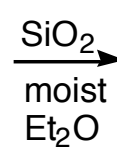

$\mathrm{Et}_{2} \mathrm{O}$

Scheme 3. Cycloadduct $\mathbf{1 0}$ and the lit. proposed structures for its hydrolysis

\section{RESULTS AND DISCUSSION}

\section{Cycloadditions of $2 \mathrm{H}$-azirines to 1,3-diphenylisobenzofuran and isobenzofuran}

The only literature on cycloadditions of azirines to 1,3-diphenylisobenzofuran are reports in the early seventies by Nair ${ }^{5}$ and Hassner and Anderson. ${ }^{2}$ Recently, we have reacted methyl 2-(2,6-dichlorophenyl)2H-azirine-3-carboxylate 11 with 1,3-diphenylisobenzofuran. The endo kinetic product (12a) was obtained if strict reaction conditions were observed. If the reaction temperature was allowed to rise to refluxing THF the exo thermodynamic product (13a) was formed exclusively. A pure specimen of the endo adduct could be fully converted into the exo isomer by refuxing it in THF and also a slow 
conversion could be observed by ${ }^{1} \mathrm{H}$ NMR at room temperature. It is likely that the endo product suffers a retro Diels-Alder giving back the reagents that will equilibrate to the thermodynamically more stable exo adduct. This suggestion was first made by Nair in his work on cycloadditions of azirines to 1,3diphenylisobenzofuran. ${ }^{5}$ The cycloaddition of azirine 11 with isobenzofuran occurs at room temperature and is complete after $16 \mathrm{~h}$. A mixture of the endo and the exo products was formed [1.3 (exo):1 (endo) ratio]. Curiously reflux of the endo/exo mixture of adducts $\mathbf{1 2} \mathbf{b}$ and $\mathbf{1 3 b}$ gave a mixture of exo adduct $\mathbf{1 3 b}$ and the hydrolysis product of the endo adduct $\mathbf{1 2 b}$, compound 22. Reflux of a clean sample of the endo adduct in dry ether showed exclusive formation of compound 22. This result shows the greater sensitivity of the endo cycloadduct to hydrolysis than that of the exo cycloadduct. The same product 22 was obtained by treatment of a solution of $\mathbf{1 2 b}$ in DCM with silica. The main difference between the endo and exo cycloadducts in their ${ }^{1} \mathrm{H}$ NMR spectra is the chemical shift of the aziridine proton. This is at $2.42 \mathrm{ppm}$ lower field in the exo adduct than in the endo product. This effect can be explained by opposite effects in both compounds: the influence of the bridge oxygen on the aziridine proton that lies close to it in the exo adduct structure, shifting the aziridine proton to lower field $\left({ }_{\mathrm{H}}=4.15 \mathrm{ppm}\right)$, and to the aromatic ring at the back of the endo structure, that shifts the aziridine proton to higher field ( $\left.{ }_{\mathrm{H}}=1.86 \mathrm{ppm}\right)$, (see structures 12 and 13 in scheme 4)

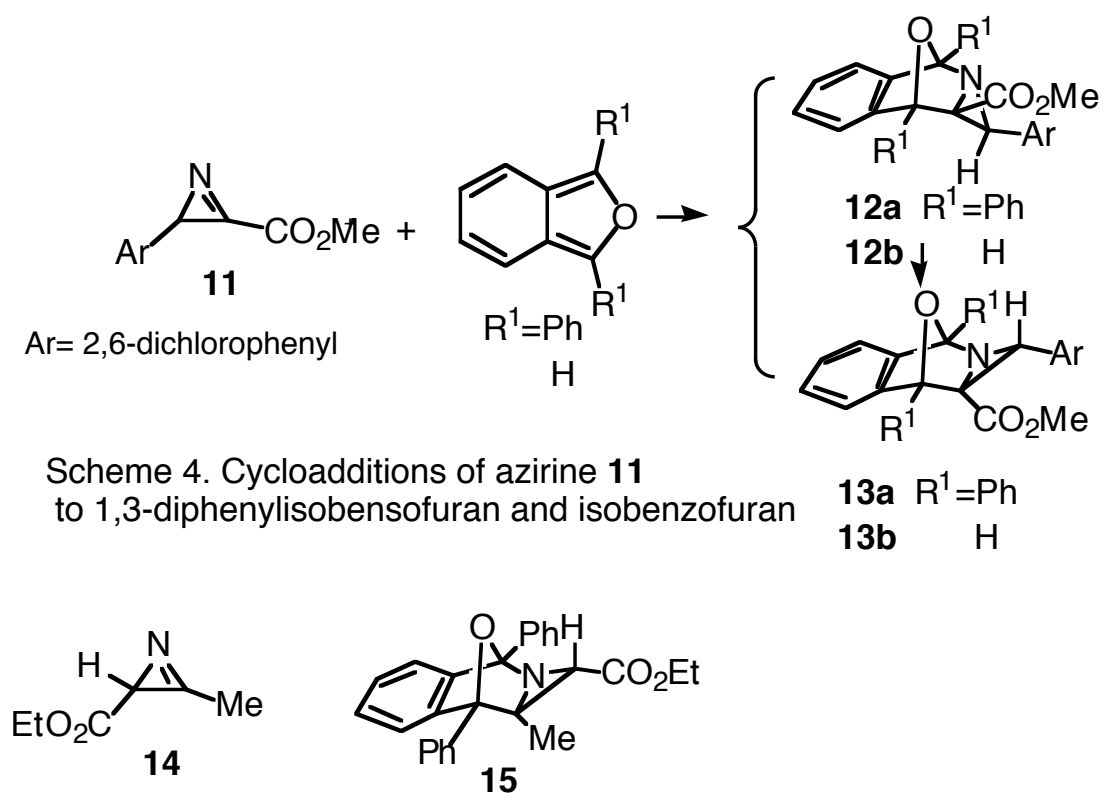

Figure 1. 2H-azirine 14 and its cycloadduct 15

Cycloaddition reactions of less electrophilic azirine 14 to 1,3-diphenylisobenzofuran were attempted both in refluxing toluene and in presence of $\mathrm{ZnCl}_{2}$ at room temperature. In the first case the cycloadduct 15 was obtained after $22 \mathrm{~h}$ (Figure 1). In the presence of the Lewis acid catalyst the reaction occurs at $\mathrm{rt}$ in 1.5 days but the cycloadduct suffers hydrolysis, compound 25 being isolated in $67 \%$ yield after flash 
chromatography. Lewis acid catalysis was employed recently by Somfai et al. ${ }^{6}$ in cycloadditions of $2 \mathrm{H}$ azirines to several dienes, but this is the first case where such catalysis was used in a reaction of $2 \mathrm{H}$ azirine with a furan. The extreme sensitivity to acid of the aminal function in the cycloadduct promotes the hydrolysis process. Even so, as described below, the reaction can be turned to advantage from a synthetic point of view.

The reaction of 2-tert-butyl $2 \mathrm{H}$-azirine with 1,3-diphenylisobenzofuran described by Hassner and Anderson was repeated with the aim of re-examining the structure proposed for the methanolysis product of the cycloadduct 10. All the analytical data for cycloadduct $\mathbf{1 0}$ is coincident with the literature results.

\section{Reaction of the cycloadducts with oxygen nucleophiles}

Furanol 16 was obtained before by treatment of the exo cycloadduct 13a with silica in DCM. ${ }^{1}$ We now treated a solution of the endo adduct 12a with silica and observed the formation of the furanol 17 in $94 \%$ yield as a single isomer (Figure 2). The stereochemistry at 3-C is unkown. When 12a was treated with methanol for $24 \mathrm{~h}$ at room temperature a 1:1 mixture of the cis isomer $\mathbf{1 8}$ and trans isomer $\mathbf{1 9}$ was obtained. The mixture could not be separated by chromatography: the same ratio of isomers was obtained in each one of the column fractions.

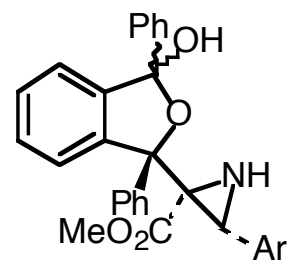

16

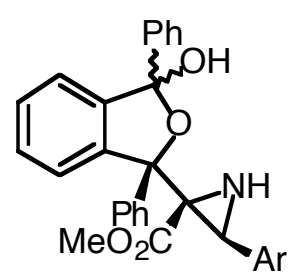

17

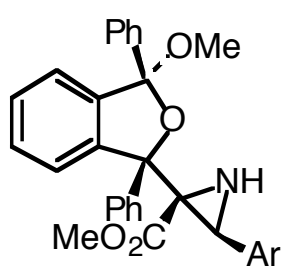

18

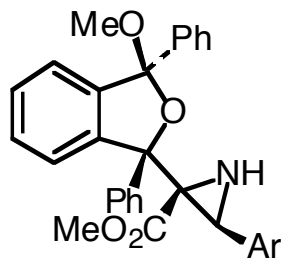

19

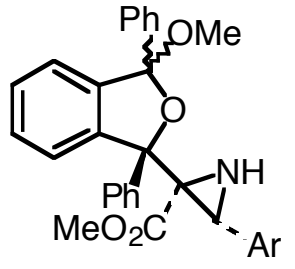

20

Figure 2. Hydrolysis and methanolysis products obtained from endo and exo adducts 12a and 13a

The exo adduct 13a needed acid or base catalysis to react with water at room temperature. But reaction of 13a with methanol progress cleanly in reflux giving a single isomer. An equilibrium between the starting cycloadduct 13a and the methanol adduct 20 prevents reaction to achive completion. The best yield of product $\mathbf{2 0}$ is $31 \%$ after crystallization. A solution of $\mathbf{2 0}$ in $\mathrm{CDCl}_{3}$ contained in an NMR tube and left at room temperature for 15 days gave a mixture of the cycloadduct 13a and the adduct 20 in a 2:1 ratio. Major features in the ${ }^{1} \mathrm{H}$ NMR spectra of furanols 16-20 (23, 24 and 27) are the coupling constant of the $\mathrm{CH}$ aziridine proton to its neighbouring $\mathrm{NH}$ and their respective chemical shifts. The $\mathrm{CH}$ appears around 3.0-3.6 ppm as well as the NH. In each compound the $\mathrm{NH}$ is always upper field compared to the $\mathrm{CH}$. The coupling constant between the $\mathrm{CH}$ and the $\mathrm{NH}$ proton is $c a .10 \mathrm{~Hz}$. 
The cycloadducts of $2 \mathrm{H}$-azirines with isobenzofuran have as a start the advantage of having hydrogens at position 1 and 3 instead of phenyl groups, which should allow the stereochemistry of the hydrolysis and methanolysis adducts to be assigned by ${ }^{1} \mathrm{H}$ NMR. Adducts formed in the reaction of the azirine 11 with isobenzofuran proved to behave differently from the adduct of the same azirine with 1,3diphenylisobenzofuran in the presence of oxygen nucleophiles; in some cases tetrahydroisoquinolines were obtained rather than furanols. The exo adduct $\mathbf{1 3 b}$ after refluxing in methanol furnishes $92 \%$ yield of the cis tetrahydroisoquinoline 21. The cis structure was confirmed by X-ray crystallography (Figure 3).

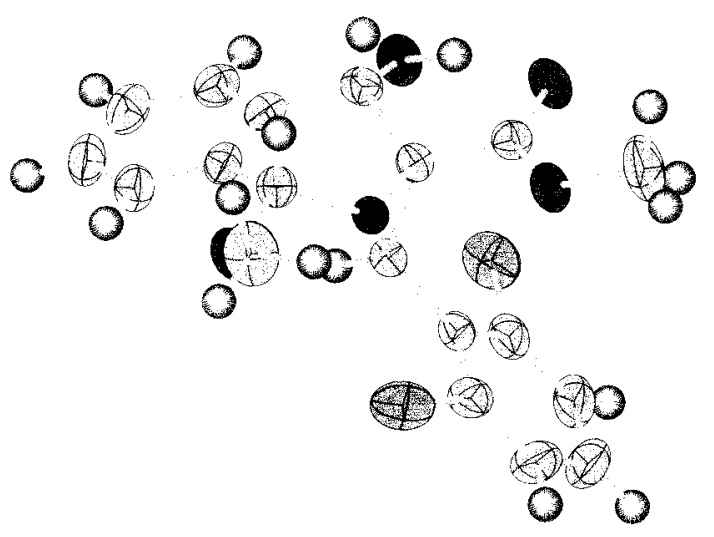

Figure 3. The molecular structure of compound 21

Treatment of the endo adduct 12b with silica in DCM gave the tetrahydroisoquinoline 22, in $93 \%$ yield, after stirring the solution $24 \mathrm{~h}$. The sterochemistry of compound 22 was assigned on the basis of a NOESY experiment that showed that 3-H and 8- $\mathrm{H}$ are close to 1-H (Figure 4). Major feaures of these tetrahydroquinolines in ${ }^{1} \mathrm{H}$ NMR spectra are the coupling of $3-\mathrm{H}$ and $8-\mathrm{H}$ with the hydrogen of the geminal $\mathrm{OH}$ group whenever it exists. ${ }^{13} \mathrm{C}$ NMR spectra are significantly different from those of the furanols. Chemical shifts of the tetrahedral carbon atoms attached to the oxygens are 25-30 ppm lower than the carbons attached to the oxygen in the five membered ring of furanols. This change is possibly due to the difference in strain of the two ring systems: the six memered ring in the tetrahydroquinoline and the five membered ring in the furanols.

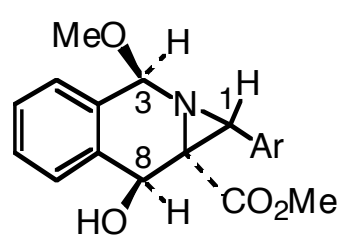

21

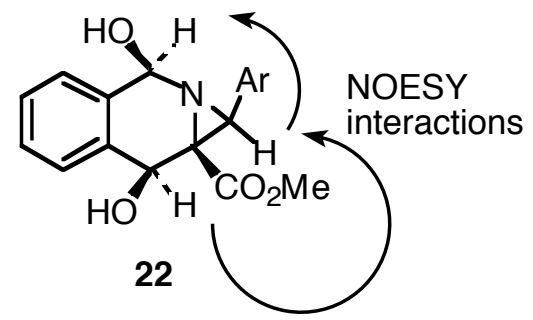

22

Figure 4. Hydrolysis product obtained from cycloadduct $12 b(22)$; methanolysis product obtained from cycloadduct $13 b(21)$ 
Unexpectedly treatment of $\mathbf{1 2 b}$ with methanol at room temperature gave again a 1:1 mixture of furanol isomers 23 and 24 (Figure 5). The trans isomer $\mathbf{2 3}$ is proposed on the basis of a small homoallylic coupling constant $(1.2 \mathrm{~Hz})$ between $1-\mathrm{H}$ and $3-\mathrm{H}$ that is well observable after $\mathrm{D}_{2} \mathrm{O}$ exchange. Very sharp singlets were recorded for the corresponding protons in the other isomer (24). The two isomers were fully separated by flash chromatography, the trans isomer being obtained in $29 \%$ yield and the cis isomer in $38 \%$ yield.

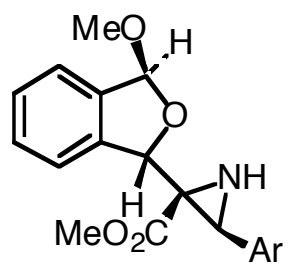

23

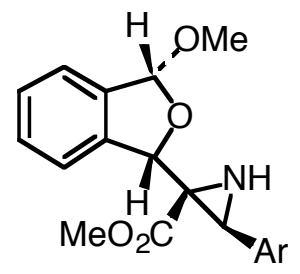

24

Figure 5. Methanolysis products obtained from cycloadduct 12b

Compound $\mathbf{2 5}$ is the hydrolysis product obtained directly from the mixture derived from the cycloaddition of the azirine $\mathbf{1 4}$ to 1,3-diphenylisobenzofuran in the presence of $\mathrm{ZnCl}_{2}$. An $\mathrm{X}$-ray determination has shown the structure to be the cis furanol (Figure 6).

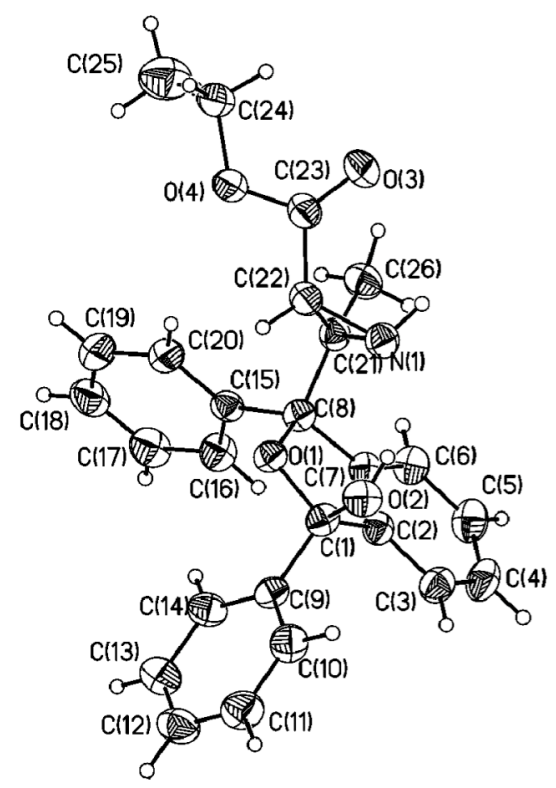

Figure 6. The molecular structure of compound 25

We observed that compound $\mathbf{2 5}$ can eliminate $1 \mathrm{~mol}$ of water if it is refluxed in toluene in the presence of $4 \AA$ molecular sieves to give back the cycloadduct 15 (scheme 5). So, the cycloadduct 15 that is very unstable in the presence of $\mathrm{ZnCl}_{2}$ can be trapped as its adduct $\mathbf{2 5}$ and used later in its original form just by 
heating 25 for some hours. The adduct 15 can also be obtained from azirine 14 and diphenylisobenzofuran after $22 \mathrm{~h}$ in refluxing toluene.

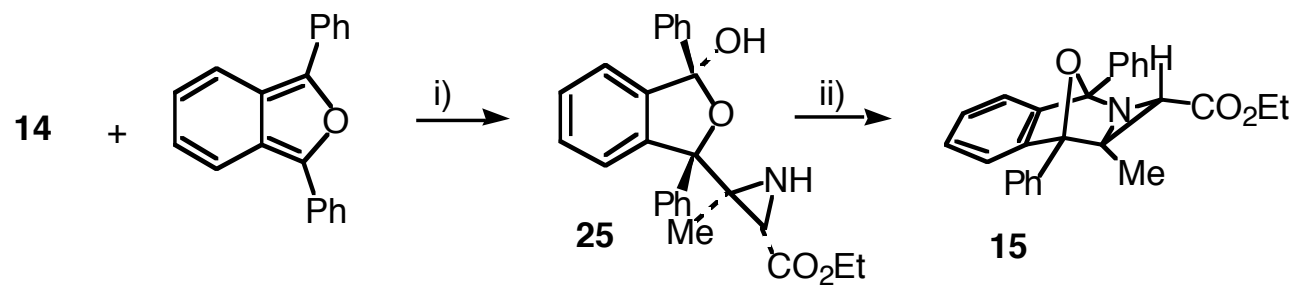

Scheme 5. Cycloaddition of azirine 14 to 1,3-diphenylisobensofuran.

i) $\mathrm{ZnCl}_{2}$, r.t., 1.5 days; ii) reflux in toluene, $16 \mathrm{~h}, 4 \AA$ molecular sieves

The cycloadduct $\mathbf{1 0}$ first obtained by Hassner and Anderson was treated with methanol under the conditions referred in their publication. ${ }^{2}$ A solid was formed that was shown to be the furanol structure 27 and not a tetrahydroisoquinoline $\mathbf{2 8}$, as was stated before (Figure 7).
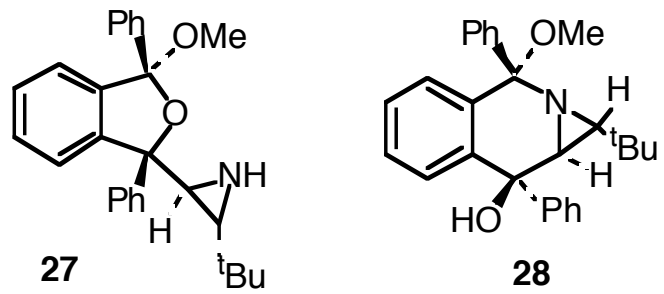

Figure 7. The correct structure for the methanolysis product of cycoadduct 10, structure $\mathbf{2 7}$ and the lit. proposed structure, compound 28.

The main difference between the two structures in the ${ }^{1} \mathrm{H}$ NMR would be the coupling between the $\mathrm{NH}$ and the adjacent $\mathrm{CH}$ in the aziridine moiety that is typical of the furanol compounds, and the coupling between $1-\mathrm{H}$ and $3-\mathrm{H}$ to the respective geminal $\mathrm{OH}$, expected for the tetrahydroisoquinoline compounds. The methanol adduct of cycloadduct 10, compound 27 showed a broad doublet of doublets at ${ }_{\text {H }} 2.60(J$ $=6.6$ and $2.7 \mathrm{~Hz})$, a doublet at ${ }_{\mathrm{H}} 2.40(J=9.3 \mathrm{~Hz})$ and a broad triplet at ${ }_{\mathrm{H}} 1.56(J=7.8 \mathrm{~Hz})$. The first two signals collapse into a sharp doublet at ${ }_{\mathrm{H}} 2.60(\mathrm{~J}=2.7 \mathrm{~Hz})$ and a broad singlet at ${ }_{\mathrm{H}} 2.40$ after $\mathrm{D}_{2} \mathrm{O}$ treatment. The triplet disappears after $\mathrm{D}_{2} \mathrm{O}$ treatment. The $2.7 \mathrm{~Hz}$ coupling constant is due to $3-\mathrm{H}$ to $2-\mathrm{H}$ trans coupling in the aziridine. The broad singlet observed after $\mathrm{D}_{2} \mathrm{O}$ exchange in one of the aziridine $\mathrm{C}-\mathrm{H}$ is shading the $2.7 \mathrm{~Hz}$ coupling constant with its trans vicinal $\mathrm{H}$, that is visible in the other aziridine $\mathrm{CH}$. The NH signal appeared as a broad triplet with a coupling constant of $7.8 \mathrm{~Hz}$. This lies between the values of 9.3 and $6.6 \mathrm{~Hz}$ that are observed for the coupling constants of the two $\mathrm{CH}$ with its vicinal $\mathrm{NH}$. That value as well as the broad triplet signal can be interpreted as a non resolved doublet of doublets. The 
confirmation of the furanol structure and the stereochemistry was obtained by an X-ray crystal structure determination (Figure 8).

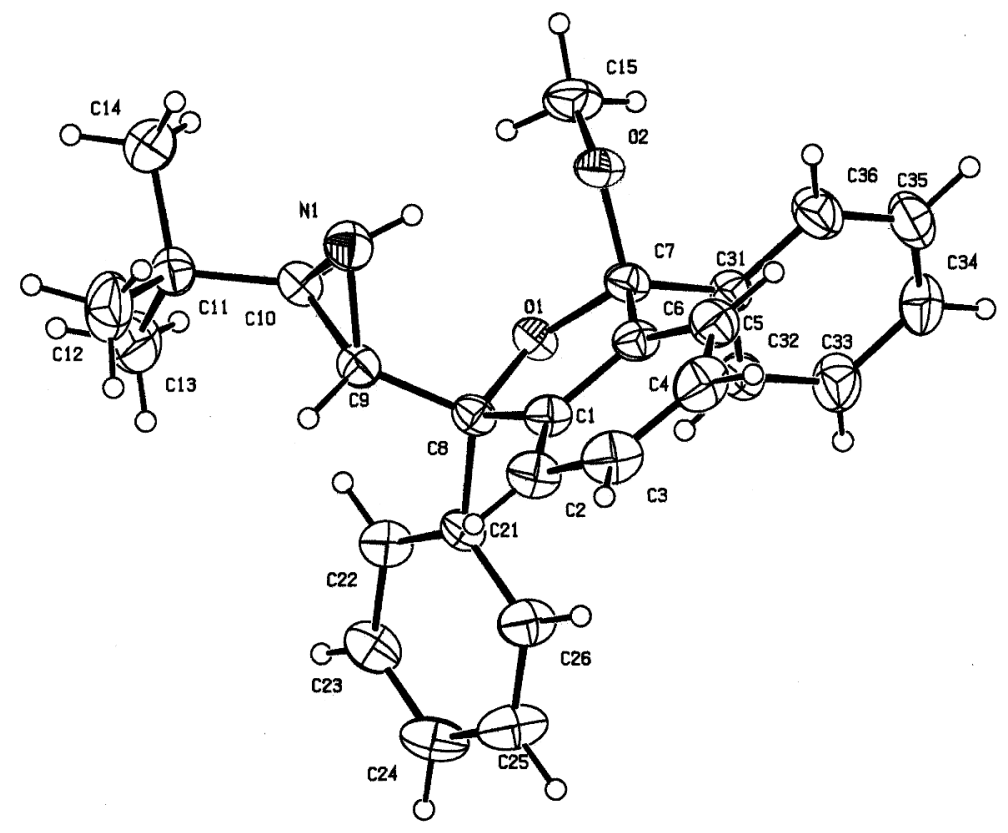

Figure 8. The molecular structure of compound 27

The cycloadduct 10 was also treated with $\mathrm{LiAlH}_{4}$ according to the literature procedure to see if in this case the six membered ring is preserved. ${ }^{1} \mathrm{H}$ NMR spectra either in $\mathrm{CDCl}_{3}$ or $\mathrm{C}_{6} \mathrm{D}_{6}$ showed no $\mathrm{NH}-\mathrm{CH}$ coupling in the aziridine moiety region which led us to conclude that the compound would be a tetrahydroisoquinoline. This product is reported as a solid, m.p. $66{ }^{\circ} \mathrm{C}$, but we could not crystallize our sample despite several attempts. The IR band registered for the mobile proton is $\mathrm{cm}$ br a value that is near the literature $\mathrm{cm}$ br The comparison of the ${ }^{1} \mathrm{H}$ NMR spectra now obtained and that in the literature showed a significant difference in the peak corresponding to $3-\mathrm{H}$ : a singlet at ${ }_{\mathrm{H}}=4.37$ as the value reported, and a singlet at ${ }_{\mathrm{H}}=5.33$ in our spectrum. All the others signals match quite well with the results published. So we conclude that in this case the tetrahydroquinoline structure 29 suggested by Hassner and Anderson is correct (Figure 9).<smiles>CC(C)[C@@H]1[C@H](c2ccccc2)c2ccccc2[C@]1(O)c1ccccc1</smiles>

29

Figure 9. Structure 29 obatined by reaction of the adduct 10 with $\mathrm{LiAlH}_{4}$ 
In conclusion, tetrahyroquinolines were obtained with excellent yields either from the endo or the exo cycloadduct of the methyl 2-(2,6-dichlorophenyl)-2 $\mathrm{H}$-azirine-3-carboxylate with isobenzofuran as single isomers. Also benzofuranols were obtained in one case as a mixture of isomers. 1,3Diphenylisobenzofuran adducts always gave benzofuranols as the hydrolysis or methanolysis products. Reaction of a less electrophilic azirine, the ethyl $2 H$-azirine-2-carboxylate with 1,3diphenylisobenzofuran was made possible at room temperature in the presence of $\mathrm{ZnCl}_{2}$. The hydrolysis reaction that followed the cycloaddition in the acidic conditions used could be reversed to give back the original cycloadduct. Cycloadduct of the tert-butyl $2 \mathrm{H}$-azirine to 1,3-isobenzofuran was reacted with methanol in the conditions reported in literature ${ }^{2}$ and the structure of methanol adduct rectified. Reaction of the same cycloadduct with $\mathrm{LiAlH}_{4}$ gave the tetrahydroquinoline reported earlier. ${ }^{2}$

\section{EXPERIMENTAL}

\section{General}

${ }^{1}$ H NMR spectra were recorded on a Varian Unity Plus 300 (300MHz) spectrometer. Multiplicities are recorded as broad peaks (br), singlets (s), doublets (d), triplets (t), quartets (q) and multiplets (m). $J$ values are in Hz. Infrared spectra were recorded on a Bomem MB 104 or on a Perkin-Elmer 1600 FT-IR spectrometer. Samples were run as nujol mulls. Mass spectra were recorded on a VG Autospec M. machine as electron impact spectra $(70 \mathrm{eV})$. Microanalyses were performed in a LECO-CHNS-932 machine. Melting points (m.p.) were determined on a Gallenkamp block and are uncorrected. Dry column flash chromatography was carried out using Kieselgel 60 and water pump vacumm. Thin layer chromatography (TLC) was carried out on $0.25 \mathrm{~mm}$ silica gel layer 60DC-Ferigplatter Durasil-25 UV254. Tetrahydrofuran (THF) was dried over sodium using benzophenone as indicator. Toluene was dried over sodium after fractional distillation. Dichloromethane (DCM) and methanol were either dried over $\mathrm{CaH}_{2}$ or used as purchased. Dry flash chromatography was performed on silica gel $60<0.063 \mathrm{~mm}$ for columm chromatography. Petroleum ether $40-60{ }^{\circ} \mathrm{C}$ was distilled before use. The 2-tert-butyl $2 \mathrm{H}$-azirine was obtained by pyrolysis of $\quad$-azidostyrene, ${ }^{7}$ the methyl 2-(2,6-dichlorophenyl)-2 $H$-azirine-3-carboxylate 11 was obtained by pyrolysis of the respective -azido acrylate ${ }^{8}$ and the azirine $\mathbf{1 4}$ by a Neber type reaction according to the Zwanenburg procedure. ${ }^{3}$ Isobenzofuran was obtained according to Man et al. ${ }^{9}$

\section{Methyl


Azirine 11 (1.90 g, $7.78 \mathrm{mmol})$ was added to a solution of isobenzofuran $(9.00 \mathrm{mmol})$ freshly prepared in toluene $(60 \mathrm{~mL})$. The solution was kept at $\mathrm{rt}$ for $16 \mathrm{~h}$. The solvent was removed by evaporation to leave an oil, that proved, by ${ }^{1} \mathrm{H}$ NMR, to be a mixture of endo and exo adducts (1:1.3). Dry flash column chromatography [silica; pet. ether/ether; gradient polarity] gave three fractions: (i) the exo isomer 13b (1.16 g, $41 \%$ ), m.p. $122.8-125.0{ }^{\circ} \mathrm{C} .{ }^{1} \mathrm{H}$ NMR $\left(300 \mathrm{MHz}, \mathrm{CDCl}_{3}\right): \delta=7.45(\mathrm{dd}, J=5.4,4.8 \mathrm{~Hz}, 2 \mathrm{H})$, 7.29 (d, $J=7.8 \mathrm{~Hz}, 2 \mathrm{H}), 7.22-7.19(\mathrm{~m}, 2 \mathrm{H}), 7.15$ (t, $J=7.8 \mathrm{~Hz}, 1 \mathrm{H}), 6.13(\mathrm{~s}, 1 \mathrm{H}), 5.78(\mathrm{~s}, 1 \mathrm{H}), 4.15$ (s, $1 \mathrm{H}), 3.39$ (s, $3 \mathrm{H}, \mathrm{OMe}) .{ }^{13} \mathrm{C}$ NMR $\left(75 \mathrm{MHz}, \mathrm{CDCl}_{3}\right): \delta=168.2$ (CO), 143.6 (C), 143.1 (C), 135.7 (C), $131.0(\mathrm{C}), 128.9(\mathrm{CH}), 128.1(\mathrm{CH}), 127.6(\mathrm{CH}), 127.2(\mathrm{CH}), 121.7(\mathrm{CH}), 120.5(\mathrm{CH}), 93.3(\mathrm{CH})$, $77.0(\mathrm{CH}), 54.0(\mathrm{C}), 52.1(\mathrm{OMe}), 48.4(\mathrm{CH})$. IR (Nujol Mull): $=1721,1582,1558 \mathrm{~cm}^{-1} . \mathrm{C}_{18} \mathrm{H}_{13} \mathrm{Cl}_{2} \mathrm{NO}_{3}$ (362.21): calcd. C 59.69, H 3.62, N 3.87; found C 59.77, H 3.79, N 3.96.

(ii) The second fraction gave the endo isomer 12b (0.53 g, $19 \%)$, m.p. 126-127 ${ }^{\circ} \mathrm{C} .{ }^{1} \mathrm{H}$ NMR (300 MHz, $\left.\mathrm{CDCl}_{3}\right): \delta=7.55-7.45(\mathrm{~m}, 1 \mathrm{H}), 7.40-7.30(\mathrm{~m}, 3 \mathrm{H}), 7.19(\mathrm{~d}, J=7.2 \mathrm{~Hz}, 2 \mathrm{H}), 7.08(\mathrm{t}, J=7.2 \mathrm{~Hz}, 1 \mathrm{H})$, $6.39(\mathrm{~s}, 1 \mathrm{H}), 6.35(\mathrm{~s}, 1 \mathrm{H}), 3.63(\mathrm{~s}, 3 \mathrm{H}, \mathrm{OMe}), 1.86(\mathrm{~s}, 1 \mathrm{H}) \cdot{ }^{13} \mathrm{C} \mathrm{NMR}\left(75 \mathrm{MHz}, \mathrm{CDCl}_{3}\right): \delta=169.6$ (CO), $139.1(\mathrm{C}), 138.4(\mathrm{C}), 134.7(\mathrm{C}), 131.0(\mathrm{C}), 128.8(\mathrm{CH}), 128.6(\mathrm{CH}), 128.5(\mathrm{CH}), 128.0(\mathrm{CH}), 120.6$ $(\mathrm{CH}), 120.3(\mathrm{CH}), 94.8(\mathrm{CH}), 81.9(\mathrm{CH}), 59.0(\mathrm{CH}), 54.7(\mathrm{C}), 52.7(\mathrm{OMe})$. IR (Nujol Mull): = 1747, 1582, $1559 \mathrm{~cm}^{-1} . \mathrm{C}_{18} \mathrm{H}_{13} \mathrm{Cl}_{2} \mathrm{NO}_{3}$ (361.21): calcd. C 59.69, H 3.62, N 3.87; found C 59.63, H 3.81, N 3.94.

(iii) The third fraction gave the 3,8-dihydroxyazirino[1,2,b]isoquinoline 22 (0.42 g, 14\%), m.p. 153-155 ${ }^{\circ} \mathrm{C}$, identified by comparison of its ${ }^{1} \mathrm{H}$ NMR with the ${ }^{1} \mathrm{H}$ NMR an authentic sample (see its synthesis ahead).

Ethyl 3,8-Diphenyl-8a-methyl-1,3,8,8a-tetrahydro-3,8-epoxyazirin[1,2-b] isoquinoline-1-carboxylate 15 and ethyl 2-methyl-2-(3-hydroxy-1,3-diphenyl-1,3-dihydroisobenzofuran-1-yl)aziridine-3carboxylate 25

i) The azirine $14(0.79 \mathrm{~g}, 6.21 \mathrm{mmol})$ was dissolved in dry toluene $(50 \mathrm{~mL})$ and 1,3diphenylisobenzofuran (0.7 eq., $1.17 \mathrm{~g}, 4.35 \mathrm{mmol})$ added. The mixture was refluxed for $22 \mathrm{~h}$. The solvent was removed leaving a yellow oil that was subjected to dry flash chromatography [silica; pet. ether/ether; polarity gradient]. The first fraction was the starting 1,3-diphenylisobenzofuran $(0.1 \mathrm{~g}, 0.37$ $\mathrm{mmol})$ and the second fraction gave the product 15 obtained as an oil (1.27 g, $3.12 \mathrm{mmol}, 73.5 \%)$. Crystalization of the oil from pet. ether/ether gave a pale yellow solid, m.p. 139-141 ${ }^{\circ} \mathrm{C} .{ }^{1} \mathrm{H}$ NMR (300 $\mathrm{MHz}, \mathrm{CDCl}_{3}$ ): $\delta=7.81-7.74(\mathrm{~m}, 4 \mathrm{H}), 7.60-7.45$ (m, $\left.6 \mathrm{H}\right), 7.37$ (br. d, $\left.J=6.9 \mathrm{~Hz}, 1 \mathrm{H}\right), 7.28(\mathrm{dt}, J=7.5$ $\mathrm{Hz}, 1.5 \mathrm{~Hz}, 1 \mathrm{H}), 7.22$ (dt, $J=7.5 \mathrm{~Hz}, 1.5 \mathrm{~Hz}, 1 \mathrm{H}), 7.11$ (br. d, $J=6.9 \mathrm{~Hz}, 1 \mathrm{H}), 4.27$ (dq, $J=7.2,3.0 \mathrm{~Hz}$, 
$2 \mathrm{H}), 3.76(\mathrm{~s}, 1 \mathrm{H}), 1.31(\mathrm{t}, J=7.2 \mathrm{~Hz}, 3 \mathrm{H}), 1.29(\mathrm{~s}, 3 \mathrm{H}) .{ }^{1} \mathrm{H}$ NMR $\left(300 \mathrm{MHz}, \mathrm{C}_{6} \mathrm{D}_{6}\right): \delta=8.02(\mathrm{dd}, J=$ 8.1, 1.5 Hz, $2 \mathrm{H}), 7.77$ (dd, $J=8.1,1.5 \mathrm{~Hz}, 2 \mathrm{H}), 7.25-7.05(\mathrm{~m}, 7 \mathrm{H}), 7.05-6.84(\mathrm{~m}, 3 \mathrm{H}), 3.95(\mathrm{~s}, 1 \mathrm{H})$, $3.90(\mathrm{dq}, J=7.2,3.3 \mathrm{~Hz}, 2 \mathrm{H}), 1.40(\mathrm{~s}, 3 \mathrm{H}), 0.83(\mathrm{t}, J=7.2 \mathrm{~Hz}, 3 \mathrm{H}) \cdot{ }^{13} \mathrm{C} \mathrm{NMR}\left(75.5 \mathrm{MHz}, \mathrm{CDCl}_{3}\right): \delta=$ 168.5 (CO), $148.0(\mathrm{C}), 145.2(\mathrm{C}), 133.4(\mathrm{C}), 132.4(\mathrm{C}), 129.4(\mathrm{CH}), 129.1(\mathrm{CH}), 128.9(\mathrm{CH}), 128.6(\mathrm{CH})$, $128.3(\mathrm{CH}), 127.5(\mathrm{CH}), 127.1(\mathrm{CH}), 127.0(\mathrm{CH}), 121.5(\mathrm{CH}), 120.7(\mathrm{CH}), 101.5(\mathrm{C}), 90.6(\mathrm{C}), 61.2$ $\left(\mathrm{CH}_{2}\right), 52.6(\mathrm{C}), 45.6(\mathrm{CH}), 14.3(\mathrm{Me}), 11.6(\mathrm{Me})$. IR (Nujol Mull): $=1746 \mathrm{~cm}^{-1} . \mathrm{C}_{26} \mathrm{H}_{23} \mathrm{NO}_{3}(397.47)$ : calcd. C 78.57, H 5.83, N 3.52; found: C 78.40, H 5.92, N 3.56.

ii) Compound 25 (0.51 g, $1.23 \mathrm{mmol})$ was dissolved in dry toluene $(50 \mathrm{ml})$ and $4 \AA$ molecular sieves were added to the solution. The solution was refluxed for $16 \mathrm{~h}$. The molecular sieves were filtered off and the solvent was removed under reduce pressure to give an oil, that proved to be mainly the desired product. Crystallization from diethyl ether/pet. ether gave a pale yellow solid, compound 15 (0.28 g, 0.67 mmol, $55 \%)$.

\section{Methyl 3-(2,6-Dichlorophenyl)-2-(1,3-diphenyl-3-hydroxy-1,3-dihydroisobenzofuran-1-yl)aziridine-}

\section{2-carboxylate 17}

Silica gel (particle size $<0.063 \mathrm{~mm})(1.0 \mathrm{~g})$ was added to a solution of compound 12a $(0.36 \mathrm{~g}, 0.70 \mathrm{mmol})$ in DCM $(25 \mathrm{ml})$ at room temperature. After $36 \mathrm{~h}$ the silica was filtered off and washed with ether. The solvent and washings were evaporated to leave a solid $(0.35 \mathrm{~g}, 0.66 \mathrm{mmol}, 94 \%)$, m.p. $165-169{ }^{\circ} \mathrm{C} .{ }^{1} \mathrm{H}$ NMR (300 MHz, $\mathrm{CDCl}_{3}$ ): $\delta=7.86$ (br. s, $2 \mathrm{H}$ ), 7.45-7.20 (m, $14 \mathrm{H}$ ), 7.10 ( br. m, $1 \mathrm{H}$ ), 5.64 ( br. s, $1 \mathrm{H}$, $\mathrm{OH}), 3.64$ (br. s, $1 \mathrm{H}, \mathrm{CH}$ aziridine), 3.24 (s, $3 \mathrm{H}$ ), 3.05 (br s, $1 \mathrm{H}, \mathrm{NH}) .{ }^{13} \mathrm{C} \mathrm{NMR}\left(75 \mathrm{MHz}, \mathrm{CDCl}_{3}\right): \delta=$ 169.7 (CO), $142.7(\mathrm{C}), 141.7(\mathrm{C}), 136.2(\mathrm{C}), 129.7(\mathrm{CH}), 129.3(\mathrm{CH}), 129.1(\mathrm{CH}), 128.8(\mathrm{CH}), 128.5$ $(\mathrm{CH}), 127.7(\mathrm{CH}), 126.7(\mathrm{CH}), 123.8(\mathrm{CH}), 108.6(\mathrm{C}), 90.5(\mathrm{C}), 52.5(\mathrm{OMe}), 50.9(\mathrm{CH}), 43.0(\mathrm{C}) . \mathrm{IR}$

(Nujol Mull): $\quad=3406,1740,1727,1561 \mathrm{~cm}^{-1}$. HREIMS: $m / z$ calcd. for $\mathrm{C}_{30} \mathrm{H}_{23} \mathrm{Cl}_{2} \mathrm{NO}_{4}-\mathrm{H}_{2} \mathrm{O} 513.0884$; found 513.0898.

\section{Methyl 3-(2,6-Dichlorophenyl)-2-(1,3-diphenyl-3-methoxy-1,3-dihydroisobenzofuran-1-yl)aziridine- 2-carboxylate 18 and 19}

A suspension of the compound 12a $(0.54 \mathrm{~g}, 1.05 \mathrm{mmol})$ in methanol $(20 \mathrm{ml})$ was left for $24 \mathrm{~h}$ and then evaporated to leave a solid $(0.48 \mathrm{~g})$ that was a clean mixture of compounds 18 and 19 (1:1 ratio) by ${ }^{1} \mathrm{H}$ NMR. Dry flash column chromatography [silica; pet. ether/ether] gave the same mixture of the two compounds (0.40 g, $70 \%) .{ }^{1} \mathrm{H}$ NMR $\left(300 \mathrm{MHz}, \mathrm{CDCl}_{3}\right): \delta=8.40(\mathrm{~d}, J=7.2 \mathrm{~Hz}, 1 \mathrm{H}), 8.05(\mathrm{~d}, J=7.5$ $\mathrm{Hz}, 1 \mathrm{H}), 7.89$ (d, $J=6.9 \mathrm{~Hz}, 2 \mathrm{H}), 7.77$ (d, $J=7.2 \mathrm{~Hz}, 2 \mathrm{H}), 7.03-7.63$ (m, $28 \mathrm{H}), 3.44$ (d, $J=10.5 \mathrm{~Hz}, 1$ $\mathrm{H}, \mathrm{NH}), 3.33(\mathrm{~d}, J=9.9 \mathrm{~Hz}, 1 \mathrm{H}), 3.25\left(\mathrm{~s}, 3 \mathrm{H}, \mathrm{OCH}_{3}\right), 3.11\left(\mathrm{~s}, 3 \mathrm{H}, \mathrm{OCH}_{3}\right), 3.06(\mathrm{~d}, J=9.9 \mathrm{~Hz}, 1 \mathrm{H}$, 
$\mathrm{NH}), 2.93(\mathrm{~d}, J=10.5 \mathrm{~Hz}, 1 \mathrm{H}), 2.80\left(\mathrm{~s}, 3 \mathrm{H}, \mathrm{OCH}_{3}\right), 2.67\left(\mathrm{~s}, 3 \mathrm{H}, \mathrm{OCH}_{3}\right) .{ }^{13} \mathrm{C} \mathrm{NMR}\left(75 \mathrm{MHz}, \mathrm{CDCl}_{3}\right): \delta$ $=169.8(\mathrm{CO}), 169.5(\mathrm{CO}), 142.3(\mathrm{C}), 142.1(\mathrm{C}), 141.7(\mathrm{C}), 141.0(\mathrm{C}), 140.8(\mathrm{C}), 140.5(\mathrm{C}), 139.8(\mathrm{C})$, $139.5(\mathrm{C}), 135.9(\mathrm{C}), 135.5(\mathrm{C}), 132.0(\mathrm{C}), 131.4(\mathrm{C}), 129.0(\mathrm{CH}), 128.81(\mathrm{CH}), 128.75(\mathrm{CH}), 128.6$ $(\mathrm{CH}), 128.5(\mathrm{CH}), 128.4(\mathrm{CH}), 128.2(\mathrm{CH}), 128.1(\mathrm{CH}), 127.9(\mathrm{CH}), 127.6(\mathrm{CH}), 127.3(\mathrm{CH}), 127.0$ $(\mathrm{CH}), 126.9(\mathrm{CH}), 126.1(\mathrm{CH}), 125.1(\mathrm{CH}), 123.7(\mathrm{CH}), 122.8(\mathrm{CH}), 111.4(\mathrm{C}), 110.2(\mathrm{C}), 89.2(\mathrm{C}), 89.0$ (C), $52.5(\mathrm{OMe}), 52.1(\mathrm{OMe}), 51.7(\mathrm{OMe}), \quad 51.1(\mathrm{OMe}), 41.7(\mathrm{C}), 39.2(\mathrm{CH}) . \mathrm{C}_{31} \mathrm{H}_{25} \mathrm{Cl}_{2} \mathrm{NO}_{4}(546.45)$ : calcd. C 68.14, H 4.61, N 2.56; found C 68.11, H 4.66, N 2.63.

\section{Methyl 3-(2,6-Dichlorophenyl)-2-(1,3-diphenyl-3-methoxy-1,3-dihydroisobenzofuran-1-yl)aziridine-}

\section{2-carboxylate 20}

A suspension of the adduct 13a $(0.50 \mathrm{~g}, 0.97 \mathrm{mmol})$ in $20 \mathrm{ml}$ of methanol was left in reflux for $48 \mathrm{~h}$. The solvent was then removed to leave an oil $(0.54 \mathrm{~g})$ that was a 1:1 mixture of the initial adduct and the product. Further heating, for $24 \mathrm{~h}$, of a new suspension of this material in fresh methanol did not force the reaction to go further. The product was obtained in a pure form by performing a dry flash chromatography (pet. ether/ether; polarity gradient), $0.16 \mathrm{~g}(31 \%)$ of a solid, m.p. $152-153{ }^{\circ} \mathrm{C} .{ }^{1} \mathrm{H}$ NMR $\left(300 \mathrm{MHz}, \mathrm{CDCl}_{3}\right): \delta=7.80-7.90(\mathrm{~m}, 3 \mathrm{H}), 7.45-7.30(\mathrm{~m}, 6 \mathrm{H}), 7.30-7.03(\mathrm{~m}, 8 \mathrm{H}), 4.28(\mathrm{~d}, J=10.5 \mathrm{~Hz}$, $1 \mathrm{H})^{\mathrm{a})}, 3.47(\mathrm{~s}, 3 \mathrm{H}, \mathrm{OMe}), 3.37(\mathrm{~s}, 3 \mathrm{H}, \mathrm{OMe}), 3.31(\mathrm{~d}, J=10.5 \mathrm{~Hz}, 1 \mathrm{H}, \mathrm{NH}){ }^{\mathrm{b})} \cdot{ }^{13} \mathrm{C} \mathrm{NMR}(75 \mathrm{MHz}$, $\left.\mathrm{CDCl}_{3}\right): \delta=169.9(\mathrm{CO}), 146.2(\mathrm{C}), 140.6(\mathrm{C}), 139.1(\mathrm{C}), 138.1(\mathrm{C}), 136.4(\mathrm{C}), 133.3(\mathrm{C}), 129.4(\mathrm{CH})$, $128.5(\mathrm{CH}), 128.4(\mathrm{CH}), 128.2(\mathrm{CH}), 127.8(\mathrm{CH}), 126.4(\mathrm{CH}), 126.1(\mathrm{CH}), 125.8(\mathrm{CH}), 123.5(\mathrm{CH})$, 111.6 (C), 91.9 (C), 51.8 (OMe), 50.7 (C), 41.7 (CH). IR (Nujol Mull): $=3261,1731,1582,1560 \mathrm{~cm}^{-1}$. $\mathrm{C}_{31} \mathrm{H}_{25} \mathrm{Cl}_{2} \mathrm{NO}_{4}(546.45) \mathrm{C} 68.14, \mathrm{H} 4.61, \mathrm{~N} 2.56$; found C 68.12, H 4.73, N 2.63.

a) collapses to a singlet after $\mathrm{D}_{2} \mathrm{O}$ exchange

b) disappears after $\mathrm{D}_{2} \mathrm{O}$ exchange

\section{Methyl 1-(2,6-Dichlorophenyl)-3-methoxy-8-hydroxy-1,3,8,8a-tetrahydroazirino [1,2-b]isoquinoline-}

\section{8a-carboxylate 21}

The adduct 13b $(1.0 \mathrm{~g}, 2.76 \mathrm{mmol})$ was dissolved in methanol $(50 \mathrm{~mL})$ and the solution was heated to reflux for 1 day. The solvent was removed to leave a solid $(1.0 \mathrm{~g}, 2.54 \mathrm{mmol}, 92 \%)$, m.p. $148.0-149.0^{\circ} \mathrm{C}$. ${ }^{1} \mathrm{H}$ NMR $\left(300 \mathrm{MHz}, \mathrm{CDCl}_{3}\right): \delta=7.77(\mathrm{~d}, J=7.5 \mathrm{~Hz}, 1 \mathrm{H}), 7.55(\mathrm{~d}, J=7.5 \mathrm{~Hz}, 1 \mathrm{H}), 7.44(\mathrm{~m}, 2 \mathrm{H}), 7.24$ $\left.(\mathrm{d}, J=7.8 \mathrm{~Hz}, 2 \mathrm{H}), 7.09(\mathrm{t}, J=7.8 \mathrm{~Hz}, 1 \mathrm{H}), 5.51(\mathrm{~d}, J=4.5 \mathrm{~Hz}, 1 \mathrm{H})^{\mathrm{a}}\right), 5.30(\mathrm{~s}, 1 \mathrm{H}), 4.05(\mathrm{~d}, J=4.5 \mathrm{~Hz}$, $1 \mathrm{H}, \mathrm{OH})^{\mathrm{b})}, 3.87(\mathrm{~s}, 3 \mathrm{H}), 3.51(\mathrm{~s}, 3 \mathrm{H}), 3.26(\mathrm{~s}, 1 \mathrm{H}) .{ }^{13} \mathrm{C} \mathrm{NMR}\left(75.5 \mathrm{MHz}, \mathrm{CDCl}_{3}\right): \delta=172.3(\mathrm{CO}), 135.6$ (C), $133.6(\mathrm{C}), 131.3(\mathrm{C}), 130.3(\mathrm{C}), 128.8(\mathrm{CH}), 128.4(\mathrm{CH}), 128.2(\mathrm{CH}), 128.1(\mathrm{CH}), 125.0(\mathrm{CH}), 124.9$ 
$(\mathrm{CH}), 89.0(\mathrm{CH}), 65.1(\mathrm{CH}), 57.9(\mathrm{OMe}), 52.5(\mathrm{OMe}), 48.2(\mathrm{C}), 40.1(\mathrm{CH})$. IR (Nujol Mull): = 3507, $1715,1561 \mathrm{~cm}^{-1} . \mathrm{C}_{19} \mathrm{H}_{17} \mathrm{Cl}_{2} \mathrm{NO}_{4}$ (394.26): calcd. C 57.88, H 4.35, N 3.55; found C 57.86, H 4.47, N 3.68.

a) collapses to a singlet after $\mathrm{D}_{2} \mathrm{O}$ exchange

b) disappears after $\mathrm{D}_{2} \mathrm{O}$ exchange

\section{Methyl 1-(2,6-Dichlorophenyl)-3,8-hydroxy-1,3,8,8a-tetrahydroazirino[1,2-b] isoquinoline-8a- carboxylate 22}

The adduct 12b $(0.15 \mathrm{~g}, 0.41 \mathrm{mmol})$ was dissolved in dichloromethane $(15 \mathrm{~mL})$ and silica gel (particle size $<0.063 \mathrm{~mm})$ ( $c a .3 .0 \mathrm{~g}$ ) was added. The suspension was left under magnetic stirring at room temperature for 1 day. The silica was removed by filtration and washed with portions of dichloromethane $(2 \times 15 \mathrm{~mL})$ and diethyl ether $(2 \times 15 \mathrm{~mL})$. The solutions were combined and evaporated to give a white solid (0.46 g, $0.38 \mathrm{mmL}, 93 \%)$, m.p. $153-155^{\circ} \mathrm{C} .{ }^{1} \mathrm{H}$ NMR (300 MHz, $\left.\mathrm{CDCl}_{3}\right): \delta=7.48$ (m, $\left.3 \mathrm{H}\right), 7.38$ $\left.(\mathrm{m}, 1 \mathrm{H}), 7.25(\mathrm{~d}, J=8.4 \mathrm{~Hz}, 2 \mathrm{H}), 7.12(\mathrm{t}, J=8.4 \mathrm{~Hz}, 1 \mathrm{H}), 6.07(\mathrm{~d}, J=7.6 \mathrm{~Hz}, 1 \mathrm{H})^{\mathrm{a}}\right), 5.77(\mathrm{~d}, J=6.6$ $\left.\mathrm{Hz}, 1 \mathrm{H})^{\mathrm{a}}, 4.27(\mathrm{~d}, J=7.6 \mathrm{~Hz}, 1 \mathrm{H}, \mathrm{OH})^{\mathrm{b}}, 3.93(\mathrm{~d}, J=6.6 \mathrm{~Hz}, 1 \mathrm{H}, \mathrm{OH})^{\mathrm{b}}\right), 3.58(\mathrm{~s}, 3 \mathrm{H}, \mathrm{OMe}), 2.54(\mathrm{~s}, 1$ H). ${ }^{13} \mathrm{C} \mathrm{NMR}\left(75 \mathrm{MHz}, \mathrm{CDCl}_{3}\right.$ ): $\delta=169.9(\mathrm{CO}), 135.4(\mathrm{C}), 132.9(\mathrm{C}), 131.2(\mathrm{C}), 130.5(\mathrm{C}), 130.1(\mathrm{C})$, $130.0(\mathrm{C}), 129.04(\mathrm{CH}), 129.0(\mathrm{CH}), 129.01(\mathrm{CH}), 128.6(\mathrm{CH}), 128.2(\mathrm{CH}), 83.6(\mathrm{CH}), 66.9(\mathrm{CH}), 52.6$ (OMe), $50.5(\mathrm{C}), 46.4(\mathrm{CH})$. IR (Nujol Mull): $=3410,3130,3072,1746,1580,1559 \mathrm{~cm}^{-1}$. HRFABMS: $m / z$ calcd. for $\mathrm{C}_{18} \mathrm{H}_{15} \mathrm{Cl}_{2} \mathrm{NO}_{4} 380.0456$; found 380.0444 .

a) collapses to a singlet after $\mathrm{D}_{2} \mathrm{O}$ exchange

b) disappears after $\mathrm{D}_{2} \mathrm{O}$ exchange

\section{Methyl 3-(2,6-Dichlorophenyl)-2-(3-methoxy-1,3-dihydroisobenzofuran-1-yl)aziridine-2-carboxylate} 23 and 24

The adduct 12b (0.63 g, $1.74 \mathrm{mmol})$ was dissolved in $40 \mathrm{~mL}$ of methanol and allowed to stay, under magnetic stirring, for $24 \mathrm{~h}$. The solvent was removed in the rotary evaporator to leave an oil $(0.50 \mathrm{~g})$ that proved to be a 1:1 mixture of two compounds. Two fractions were obtained by flash chromatography [silica; pet. ether/ether]. The first fraction gave the isomer 23 (0.20 g, $0.51 \mathrm{mmol}, 29 \%)$, m.p. 127.5129.0 ${ }^{\circ} \mathrm{C} .{ }^{1} \mathrm{H}$ NMR $\left(300 \mathrm{MHz}, \mathrm{CDCl}_{3}\right.$ ): $\delta=7.40$ (br s, $4 \mathrm{H}$ ), 7.32-7.25 (m, $\left.2 \mathrm{H}\right), 7.25-7.15(\mathrm{~m}, 1 \mathrm{H}), 6.46$ (br. s, $1 \mathrm{H})^{\mathrm{a})}, 6.17$ (br. s, $\left.1 \mathrm{H}\right)^{\mathrm{a})}, 3.57$ (s, $\left.3 \mathrm{H}, \mathrm{OMe}\right), 3.41$ (s, $\left.3 \mathrm{H}, \mathrm{OMe}\right), 3.33$ (br. d, $J=9.1 \mathrm{~Hz}, 1 \mathrm{H}$, $\mathrm{CH})^{\mathrm{b})}, 2.72(\mathrm{~d}, J=9.1 \mathrm{~Hz}, 1 \mathrm{H}, \mathrm{NH})^{\mathrm{c}}$. ${ }^{13} \mathrm{C} \mathrm{NMR}\left(75 \mathrm{MHz}, \mathrm{CDCl}_{3}\right): \delta=170.5(\mathrm{CO}, \mathrm{br}), 139.0(\mathrm{br}), 138.2$ (br), 135.5 (br), 131.0 (br), 129.2 (br), 129.0 (CH), 128.7 (CH), 128.3 (br), 123.2 (br), 122.3 (br), 107.4 $(\mathrm{CH}), 82.7(\mathrm{CH}), 53.8$ (CH or OMe), 52.8 (br), 48.3 (br), 44.1 (br). IR (Nujol Mull): = 3295, 1709, $1579,1559 \mathrm{~cm}^{-1} . \mathrm{C}_{19} \mathrm{H}_{17} \mathrm{Cl}_{2} \mathrm{NO}_{4}$ (394.26): calcd. C 57.88, H 4.35, N 3.55; found C 57.60, H 4.55, N 3.64. 
a) collapses to a sharp doublet $(J=1.2 \mathrm{~Hz})$ after $\mathrm{D}_{2} \mathrm{O}$ exchange

b) collapses to a singlet after $\mathrm{D}_{2} \mathrm{O}$ exchange

c) disappears after $\mathrm{D}_{2} \mathrm{O}$ exchange

The second fraction gave the isomer 24 (0.26 g, $0.66 \mathrm{mmol}, 38 \%)$, m.p. $133.0-134.0{ }^{\circ} \mathrm{C} .{ }^{1} \mathrm{H}$ NMR $(300$ $\left.\mathrm{MHz} \mathrm{CDCl}_{3}\right): \delta=7.15-7.25(\mathrm{~m}, 4 \mathrm{H}), 7.23(\mathrm{~d}, J=7.2 \mathrm{~Hz}, 2 \mathrm{H}), 7.10(\mathrm{t}, J=7.2 \mathrm{~Hz}, 1 \mathrm{H}), 6.25(\mathrm{~s}, 1 \mathrm{H})$, 6.04 (s, $1 \mathrm{H}), 3.61$ (s, $3 \mathrm{H}, \mathrm{OMe}$ ), 3.57 (s, $3 \mathrm{H}, \mathrm{OMe}$ ), 3.35 (br. s, $1 \mathrm{H}$ ) ${ }^{\mathrm{a}}, 2.65$ (br s, $\left.1 \mathrm{H}, \mathrm{NH}\right){ }^{\mathrm{b})} .{ }^{13} \mathrm{C}$ NMR $\left(75 \mathrm{MHz}, \mathrm{CDCl}_{3}\right): \delta=171.1(\mathrm{CO}), 138.4(\mathrm{C}), 137.9(\mathrm{C}), 135.8(\mathrm{C}), 132.0(\mathrm{C}), 129.0(\mathrm{CH}), 128.8(\mathrm{CH})$, $128.7(\mathrm{CH}), 128.0(\mathrm{CH}), 123.9(\mathrm{CH}), 123.0(\mathrm{CH}), 106.9(\mathrm{CH}), 80.8(\mathrm{CH})$, 56.1(OMe), $52.5(\mathrm{OMe}), 47.5$ ( $\mathrm{CH}$ or C), 41.1 (CH or C). IR (Nujol Mull) 3297, 1746, 1583, $1557 \mathrm{~cm}^{-1} . \mathrm{C}_{19} \mathrm{H}_{17} \mathrm{Cl}_{2} \mathrm{NO}_{4}$ (394.26): calcd. C 57.88, H 4.35, N, 3.55; found C 57.60, H 4.55, N 3.64.

a) collapses to a sharp singlet after $\mathrm{D}_{2} \mathrm{O}$ exchange

b) disappears after $\mathrm{D}_{2} \mathrm{O}$ exchange

\section{Ethyl 2-Methyl-2-(3-hydroxy-1,3-diphenyl-1,3-dihydroisobenzofuran-1-yl)aziridine-3-carboxylate} 25

The azirine $14(0.5 \mathrm{~g}, 3.9 \mathrm{mmol})$ was dissolved in dry toluene $(50 \mathrm{~mL})$ and it was added 1,3diphenylisobenzofuran (0.95 g, $3.5 \mathrm{mmol}, 0.9$ eq.) and zinc chloride (10 mg). The solution was allowed to stay at rt, under magnetic stirring, for 1.5 days. The solvent was evaporated to leave an oil, that was purified by dry flash column chromatography [silica; pet. ether/ether, polarity gradient]. After purification a solid was obtained (0.96 g, $2.33 \mathrm{mmol}, 67 \%)$, m.p. 126-128 ${ }^{\circ} \mathrm{C}$ (from diethyl ether/light petroleum). ${ }^{1} \mathrm{H}$ NMR (300 MHz, $\left.\mathrm{CDCl}_{3}\right): \delta=7.69(\mathrm{~s}, 1 \mathrm{H}), 7.60-7.50(\mathrm{~m}, 2 \mathrm{H}), 7.50-7.30(\mathrm{~m}, 8 \mathrm{H}), 7.30-7.20(\mathrm{~m}, 3 \mathrm{H})$, $4.36(\mathrm{q}, J=7.2 \mathrm{~Hz}, 2 \mathrm{H}), 3.78(\mathrm{~d}, J=7.5 \mathrm{~Hz}, 1 \mathrm{H}))^{\mathrm{a})}, 1.42(\mathrm{~s}, 3 \mathrm{H}), 1.38(\mathrm{t}, J=7.2 \mathrm{~Hz}, 3 \mathrm{H}) .{ }^{13} \mathrm{C} \mathrm{NMR}$ $\left(75.5 \mathrm{MHz}, \mathrm{CDCl}_{3}\right): \delta=170.2(\mathrm{CO}), 146.4(\mathrm{C}), 142.1(\mathrm{C}), 139.5(\mathrm{C}), 139.0(\mathrm{C}), 129.1(\mathrm{CH}), 128.7(\mathrm{CH})$, $128.5(\mathrm{CH}), 127.9(\mathrm{CH}), 127.86(\mathrm{CH}), 127.8(\mathrm{CH}), 126.3(\mathrm{CH}), 124.0(\mathrm{CH}), 123.6(\mathrm{CH}), 107.0(\mathrm{C}), 91.1$ (C), $61.9\left(\mathrm{CH}_{2}\right), 45.2(\mathrm{C}), 40.1(\mathrm{CH}), 14.4(\mathrm{Me}), 14.3(\mathrm{Me})$. IR (Nujol Mull): = 3282, 3212, 3059, 1721 $\mathrm{cm}^{-1}$. $\mathrm{C}_{26} \mathrm{H}_{25} \mathrm{NO}_{4}$ (415.49): calcd. C 75.16, H 6.06, N 3.37; found C 75.07, H 6.13, N 3.59.

${ }^{1} \mathrm{H}$ NMR (300 MHz, $\left.\mathrm{C}_{6} \mathrm{D}_{6}\right): \delta=7.95-7.85(\mathrm{~m}, 2 \mathrm{H}), 7.74(\mathrm{~s}, 1 \mathrm{H}), 7.70-7.60(\mathrm{~m}, 2 \mathrm{H}), 7.35-7.25(\mathrm{~m}, 1 \mathrm{H})$, $7.20-7.00(\mathrm{~m}, 8 \mathrm{H}), 3.82(\mathrm{dq}, J=7.2,1.8 \mathrm{~Hz}, 2 \mathrm{H}), 3.77(\mathrm{~d}, J=7.8 \mathrm{~Hz}, 1 \mathrm{H})^{\mathrm{a})}, 1.15(\mathrm{~s}, 3 \mathrm{H}), 0.90(\mathrm{~d}, J=$ $7.8 \mathrm{~Hz}, 1 \mathrm{H}, \mathrm{NH})^{\mathrm{b})}, 0.84(\mathrm{t}, J=7.2 \mathrm{~Hz}, 3 \mathrm{H})$.

a) collapses to a singlet after $\mathrm{D}_{2} \mathrm{O}$ exchange

b) disappears after $\mathrm{D}_{2} \mathrm{O}$ exchange 
The reaction was run under the conditions stated by Hassner and Anderson. The adduct $\mathbf{1 0}$ was refluxed in methanol for $24 \mathrm{~h}$. Evaporation of the solvent gave a solid that was crystalized giving colorless crystals, yield $30 \%,{ }^{2}$ m.p. $121-122{ }^{\circ} \mathrm{C}^{\text {a) }}$ (pet. ether). ${ }^{1} \mathrm{H}$ NMR $\left(300 \mathrm{MHz}, \mathrm{C}_{6} \mathrm{D}_{6}\right): \delta=7.67(\mathrm{~d}, J=7.2 \mathrm{~Hz}, 2$ H), $7.52(\mathrm{~d}, J=7.2 \mathrm{~Hz}, 6 \mathrm{H}), 7.26-7.32(\mathrm{~m}, 1 \mathrm{H}), 6.90-7.10(\mathrm{~m}, 9 \mathrm{H}), 3.17(\mathrm{~s}, 3 \mathrm{H}), 2.60(\mathrm{dd}, J=6.6,2.7$ $\left.\mathrm{Hz}, 1 \mathrm{H})^{\mathrm{b}}\right), 2.48(\mathrm{~d}, J=9.3 \mathrm{~Hz}, 1 \mathrm{H})^{\mathrm{c})}, 1.56(\mathrm{t}, J=7.5 \mathrm{~Hz}, 1 \mathrm{H}, \mathrm{NH})^{\mathrm{d})}, 1.07(\mathrm{~s}, 9 \mathrm{H}) .{ }^{1} \mathrm{H} \mathrm{NMR}(300 \mathrm{MHz}$, $\mathrm{CD}_{3} \mathrm{Cl}$ ): $\delta=7.80-7.20(\mathrm{~m}, 14 \mathrm{H}), 3.34$ (s, $\left.3 \mathrm{H}, \mathrm{OMe}\right), 2.52$ ( br. d, $J=3 \mathrm{~Hz}, 1 \mathrm{H}$ ), 2.32 (br. s, $\left.1 \mathrm{H}\right), 0.98$ (s, 9 H). ${ }^{13} \mathrm{C}$ NMR (75.5 MHz, $\mathrm{CDCl}_{3}$ ): $\delta=142.4$ (C), 141.9 (C), 140.0 (C), 129.9 (C), 129.0 (CH), 128.8 $(\mathrm{CH}), 128.7(\mathrm{CH}), 128.63(\mathrm{CH}), 128.58(\mathrm{CH}), 127.6(\mathrm{CH}), 127.1(\mathrm{CH}), 123.7(\mathrm{CH}), 111.7(\mathrm{C}), 90.9(\mathrm{C})$, $51.6(\mathrm{OMe}), 44.7(\mathrm{CH}), 42.2(\mathrm{CH}), 31.0(\mathrm{C}), 11.6(27.5)$. IR (Nujol Mull): $=3281 \mathrm{~cm}^{-1}$. $)$

a) reported $\mathrm{mp} 118^{\circ} \mathrm{C}$.

b) collapses to a sharp doublet $(J=2.7 \mathrm{~Hz})$ after $\mathrm{D}_{2} \mathrm{O}$ exchange.

c) collapses to a broad singlet after $\mathrm{D}_{2} \mathrm{O}$ exchange.

d) disappears after $\mathrm{D}_{2} \mathrm{O}$ exchange.

e) reported value $3285 \mathrm{~cm}^{-1}$.

\section{1-(tert-Butyl)-3,8-diphenyl-1,3,8,8a-tetrahydroazirino[1,2-b]isoquinoline 29}

The adduct 10 was reflux in THF in the presence of $\mathrm{LiAlH}_{4}(1.5 \mathrm{eq})$ for $24 \mathrm{~h}$, according to the procedure described by Hassner and Anderson. A foam was formed but no crystals were obtained after extensive

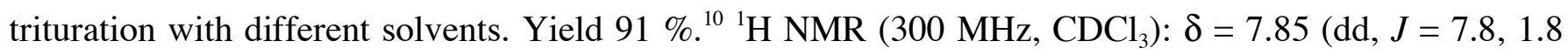
$\mathrm{Hz}, 1 \mathrm{H}), 7.40$ (dt, $J=7.5,1.5 \mathrm{~Hz}, 1 \mathrm{H}), 7.34$ (dt, $J=7.5,1.5 \mathrm{~Hz}, 1 \mathrm{H}), 7.20-6.95$ (m, $11 \mathrm{H}), 5.33$ (s, 1 $\mathrm{H}), 2.86(\mathrm{~d}, J=3 \mathrm{~Hz}, 1 \mathrm{H}), 1.62(\mathrm{~d}, J=3 \mathrm{~Hz}, 1 \mathrm{H}), 1.01(\mathrm{~s}, 9 \mathrm{H}) .{ }^{\mathrm{a}}{ }^{13} \mathrm{C} \mathrm{NMR}\left(75.5 \mathrm{MHz}, \mathrm{CDCl}_{3}\right): \delta=$ $146.0(\mathrm{C}), 143.6(\mathrm{C}), 138.7(\mathrm{C}), 133.2(\mathrm{C}), 129.4(\mathrm{CH}), 128.5(\mathrm{CH}), 128.04(\mathrm{CH}), 128.01(\mathrm{CH}), 127.98$ $(\mathrm{CH}), 127.4(\mathrm{CH}), 127.0(\mathrm{CH}), 126.9(\mathrm{CH}), 126.8(\mathrm{CH}), 72.8(\mathrm{C}), 64.3(\mathrm{CH}), 46.4(\mathrm{CH}), 45.8(\mathrm{CH}), 31.0$ (C), $27.4(\mathrm{Me})$. IR (Nujol Mull): $=3459 \mathrm{~cm}^{-1}$. )

a) described ${ }^{1} \mathrm{H}$ NMR spectrum for this compound $\delta=8.05-7.80(\mathrm{~m}, 1 \mathrm{H}), 7.65-7.0(\mathrm{~m}, 13 \mathrm{H}), 4.37(\mathrm{~s}, 1$ H), $2.86(\mathrm{~d}, J=3 \mathrm{~Hz}, 1 \mathrm{H}), 1.61(\mathrm{~d}, J=3 \mathrm{~Hz}, 1 \mathrm{H}), 1.00$ (s, $9 \mathrm{H})$.

b) described IR spectrum for this compound $3459 \mathrm{~cm}^{-1}$.

\section{Crystal structure determination of compound 21}

Crystal data: $\mathrm{C}_{19} \mathrm{H}_{17} \mathrm{Cl}_{2} \mathrm{NO}_{4}, \mathrm{M}=394.24$, monoclinic, $a=10.9897(9) \AA, b=10.2685(8) \AA, c=$ 16.2557(13) $\mathrm{\AA}, \quad=90^{\circ}, \quad=95.0230(10)^{\circ}, \quad=90^{\circ}, U=1827.4(3) \AA^{3}, \quad$ calcd $=1.433 \mathrm{~g} / \mathrm{cm}^{3}, T=$ 293(2)K, space group $P 2(1) / \mathrm{n}, Z=4$, $($ Mo-K $)=0.380 \mathrm{~mm}^{-1}, 10493$ reflections collected, $4156[R($ int $)$ $=0.0382)], R\left(F^{2}\right)=0.906, R(F)[I>2 \quad(I)]=0.0469$. 


\section{Crystal structure determination of compound 25}

Crystal data: $\mathrm{C}_{26} \mathrm{H}_{25} \mathrm{NO}_{4}, \mathrm{M}=415.47$, monoclinic, $a=11.1038(15) \AA, b=10.7831(14) \AA, c=18.409(3)$ $\AA, \quad=90^{\circ}, \quad=96.114(3)^{\circ}, \quad=90^{\circ}, U=2191.7(5) \AA^{3}, \quad$ calcd $=1.259 \mathrm{~g} / \mathrm{cm}^{3}, T=293(2) \mathrm{K}$, space group $P 2(1) / \mathrm{n}, Z=4, \quad($ Mo-K $)=0.085 \mathrm{~mm}^{-1}, 11888$ reflections collected, $4848[R($ int $\left.)=0.0420)\right]$, $R\left(F^{2}\right)=0.822, R(F)[I>2 \quad(I)]=0.0404$.

\section{Crystal structure determination of compound 27}

Crystal data: $\mathrm{C}_{27} \mathrm{H}_{29} \mathrm{NO}_{2}, \mathrm{M}=399.51$, monoclinic, $a=11.7266(10) \AA, b=9.7610(8) \AA, c=19.9243(17)$ $\AA, \quad=90^{\circ}, \quad=98.321(2)^{\circ}, \quad=90^{\circ}, U=2256.6(3) \AA^{3}, \quad$ calcd $=1.176 \mathrm{~g} / \mathrm{cm}^{3}, T=293(2) \mathrm{K}$, space group $P 2(1) / \mathrm{n}, Z=4, \quad($ Mo-K $)=0.073 \mathrm{~mm}^{-1}, 11834$ reflections collected, $4978[R($ int $\left.)=0.0533)\right]$, $R\left(F^{2}\right)=0.748, R(F)[I>2 \quad(I)]=0.0436$.

\section{Crystallography}

Data were collected with Bruker Smart-CCD 1000 difractometer (three-circle goniometer with CCD detector, FN-Mo-2K-90 radiation). Details are listed in the experimental section. CCDC-257834 (21), 257833 (25), 257832 (27) contain the supplementary crystallographic data for this paper. These data can be obtained free of charge at www.ccdc.cam.ac.uk/retrieving.html [or from the Cambridge Crystallographic Data Centre, 12 Union Road, Cambridge CB2 1EZ, UK; Fax: (internat.) + 44-1223-336033; E-mail:deposit@ccdc.cam.ac.uk].

\section{ACKNOWLEDGMENTS}

We thank Fundação para a Ciência e Tecnologia and FEDER for financial support (POCTI/QUI/32723/2000). We would also like to thank Professor Thomas L. Gilchrist for helpful discussions.

\section{REFERENCES}

1. M.J. Alves, N.G. Azoia, J.F. Bickley, A. Gil Fortes, T.L. Gilchrist, R. Mendonça, J. Chem. Soc. Perkin Trans 1, 2001, 2969-2976.

2. A. Hassner, D.J. Anderson, J. Org. Chem. 1974, 39, 2031-2036.

3. M.M.H. Verstapen, G.J.A. Ariaans, B. Zwanenburg, J. Am. Chem. Soc. 1996, 118, 8491-8492.

4. F. Palacios; A.M. Ochoa de Retana; J.G. Gil, Tetrahedron Lett., 2000, 41, 5363-5366.

5. V. Nair, J. Org. Chem. 1972, 37, 2031-2036. 
6. C.A. Ray, E. Risberg, P. Somfai, Tetrahedron Lett. 2001, 42, 9289-9291

7. A. Hassner, F.W. Fowler, J. Am. Chem. Soc. 1968, 90, 2869-2872

8. M.J. Alves, T.L. Gilchrist, J. Chem. Soc. Perkin Trans 1, 1998, 299-303.

9. Y.M. Man, T.C.W. Mak, H.N.C. Wong, J. Org. Chem. 1990, 55, 3214-3221.

10. Reported yield $78 \%$ (see reference 2 ). 